\title{
Vitoria, Suárez, and Grotius: James Brown Scott's Enduring Revival
}

\author{
Mark Somos \\ Max Planck Institute for Comparative Public Law and International \\ Law, Heidelberg, Germany \\ somos@mpil.de \\ Joshua Smeltzer \\ University of Cambridge, The Department of Politics and Interna- \\ tional Studies, Cambridge, UK \\ jrs205@cam.ac.uk
}

\begin{abstract}
This article recovers James Brown Scott's conviction in American exceptionalism, a belief that underlay both his institutional work as well as his understanding of the origins and trajectory of international law. In the first section, we discuss Scott's interpretation of Hugo Grotius as part of his tactic to make US foreign affairs policies and perspectives more compelling by presenting them as universal. In the second section, we argue that Scott's writings on the Spanish origins of international law were in fact meant to protect Anglo-American hegemony and US influence in the Americas in the face of rapidly changing geopolitical pressures. In the final section we suggest that Scott's US exceptionalism is reflected in his use of the United States Constitution and Supreme Court as a model for key international organizations. We conclude that Scott reframed Vitoria not to redress American bias but to enshrine it.
\end{abstract}

\section{Keywords}

James Brown Scott - international legal historiography - US exceptionalism - School of Salamanca 
'The idea underlying this volume is that international law is part of the English common law; that as such it passed with the English colonists to America; that when, in consequence of a successful rebellion, they were admitted to the family of nations, the new republic recognized international law as completely as international law recognized the new republic'. James Brown Scott, Cases on International Law Selected from Decisions of English and American Courts (St. Paul: West Publishing, 1922 [1906]), Preface, p. v.

'The modern law of nations of which Victoria was the expounder, Suárez the philosopher, and Grotius the systematizer, is the contribution of what we may call, and indeed must call, the Spanish School of International Law. For if Grotius was not a Spaniard by blood, he was a Spaniard in his conception of international law, and so far as the basic principles of his system are concerned, he was indubitably a member of the Spanish School'.

James Brown Scott, The Spanish Conception of International Law and of Sanctions (Oxford: Oxford University Press, 1934), p. 51.

Writing in the spring of 1939, the American international lawyer James Brown Scott set out his vision of a new international order based on 'humanity's ever advancing standard of justice.' Beginning with 'the golden days of Plato' and proceeding to the present moment, Scott interpreted the history of international law as the history of the progressive unfolding of liberal ideals of man, the state, and international politics. This new order, he proclaimed, would adhere to the promises of the American Declaration of Independence of 'Life, Liberty and the pursuit of Happiness' and radiate out to all members of the Society of Nations. Future international courts would follow the model of the United States Supreme Court and be imbued with universal jurisdiction, while nations would agree to bind themselves together in pursuit of a 'more perfect union'.2 The future of international law would be, in a word, American.

Educated at Harvard, Berlin, Heidelberg and Paris, James Brown Scott - the American 'dean of international law' - profoundly shaped the development of international law in his lifetime. ${ }^{3}$ He taught thousands of students in over a

1 James Brown Scott, Law, the State, and the International Community Vol. I (New York: Columbia University Press, 1939), p. 40.

2 Scott, Law, the State, and the International Community Vol. I, p. 36.

3 Hatsue Shinohara, US International Lawyers in the Interwar Years (Cambridge: Cambridge University Press, 2012), p. 1. 
dozen universities during his nearly 5o-year career. His casebooks on international law, equity, and contracts were standard textbooks for decades. As an administrator, he founded the law school of the University of Southern California and served as Dean of Law at the University of Illinois and professor of law at Columbia, George Washington, Johns Hopkins, and Georgetown universities.

As a serial institution-builder, in 1905 it was Scott who proposed creating the American Society of International Law (1906-) and the American Journal of International Law (1907-) and he served in leading positions in both for almost four decades. Scott was appointed Solicitor for the Department of State in 1906 and worked as US technical delegate at the 1907 Second Peace Conference at The Hague under Secretary of State Elihu Root. ${ }^{4}$ Elected to the Institute of International Law in 1908, Scott helped to establish a pan-American system of national institutes of international law, united under the umbrella of the American Institute of International Law that he founded and presided over from 1912, and which dissolved upon his death in 1943. In 1911 he became Secretary and Director of the Division of International Law at the Carnegie Endowment for International Peace, and used the Endowment's resources to support and finance the Permanent Court of Arbitration and The Hague Academy of International Law. From 1914, Scott chaired the US Neutrality Board, joining the Army's Judge Advocate General's department when the US entered the First World War in 1917. In this capacity Scott served as legal advisor to President Woodrow Wilson's Commission to Negotiate Peace in 1918, and represented the US on the Drafting Committee of the Peace Conference. ${ }^{5}$ In 1920 he was appointed adviser to the American delegation at The Hague preparing the Permanent Court of International Justice. Scott had advocated for a permanent court at least since 1897 , and he was instrumental in strategically shaping American and global opinion until his death. ${ }^{6}$ In 1927, Scott received an honorary doctorate from the University of Salamanca in recognition of his work in recovering the influence of Francisco de Vitoria and Francisco Suárez for the formation of international law. ${ }^{7}$

4 Frederic Kirgis, 'Elihu Root, James Brown Scott and the Early Years of the AsIL', Proceedings of the American Society of International Law 90 (1996), 139-43, p. 139.

5 See 'Composition and Functions of the American Commission to Negotiate Peace, May 1, 1919', in Papers Relating to the Foreign Relations of the United States, The Paris Peace Conference, 1919, Volume XI, 184/160. Available online at https://history.state.gov/historicaldocuments/frus1919Parisvi1/d245.

6 George A. Finch, Adventures in Internationalism: A Biography of James Brown Scott, ed. by William Butler (Clark: The Lawbook Exchange, 2012), p. 200. On Root and Scott calling for US public opinion to be shaped in support of international law, see Juan Pablo Scarfi, The Hidden History of International Law in the Americas (Oxford: Oxford University Press, 2017), p. 18.

7 Christopher Rossi, The Broken Chain of Being: James Brown Scott and the Origins of Modern International Law (The Hague: Kluwer Law International, 1998), p. 7. See also James Brown 
Scott did not move between all these academic, administrative, governmental and diplomatic posts; he accumulated them. As his activities show, Scott was committed to guiding international law forward along its progressive, evolutionary path. In doing so, he reflected critically upon the evolution of international law up to the present and consistently described understanding the history of international law as a vital precondition to changing it. In several academic, professional and diplomatic platforms, Scott insisted that international law's development is organic and painfully slow, and cannot be advanced without a full grasp of its history. ${ }^{8}$ Bearing in mind his various projects, their precise chronology, and his view of the potentially scientific but ineluctably historical nature of international law is essential for understanding how Scott structured and shaped the ongoing conversation about the relationship between Hugo Grotius, Francisco de Vitoria and Francisco Suárez, and for recovering the importance of the way Scott framed this relationship for the enduring but non-obvious influence of Anglo-American law and perspective on the international legal order.

Following the ongoing historical turn in international law scholarship, it is little surprise that such an omnipresent figure as James Brown Scott would undergo a renaissance. For example, Martti Koskenniemi and others have argued that Scott introduced Eurocentric bias into international law. ${ }^{9}$ Richard Tuck noted that Scott and his allies left behind a 'very misleading picture of the pre-Grotian ideas about the laws of war and peace.'. ${ }^{10}$ Anthony Anghie and Anne Orford drew on Scott to explain Vitoria's originality. ${ }^{11}$ Paolo Amorosa has recently argued that Scott used Vitoria as 'a proxy for his agenda' to recover the Catholic influence on international law and to promote feminist causes, as

Scott, El descubrimiento de América y su influjo en el derecho internacional (Madrid: Tipografía de Archivos, 1930), p. 5 .

8 James Brown Scott, 'Annual Report', Carnegie Endowment Year Book 1917, p. 106. Cited in George Finch, 'James Brown Scott, 1866-1943', American Journal of international Law 38 (1944), 183-217, p. 198. This is a consistent aspect of Scott's work across the decades: see James Brown Scott, 'The Classics and Modern Life', The School Review 17 (1909), 498-501; and James Brown Scott, Law, the State, and the International Community Vol. II (New York: Columbia University Press, 1939).

9 Martti Koskenniemi, 'Colonization of the 'Indies': The Origin of International Law?', in: $L a$ idea de la América en el pensamiento ius internacionalista del siglo XXI, ed. by Yalanda Gamarra (Zaragoza: Institución Fernando el Católico, 2010), pp. 34-63.

10 Richard Tuck, The Rights of War and Peace (Oxford: Oxford University Press, 2001), p. 11.

11 Anthony Anghie, Imperialism, Sovereignty, and the Making of International Law (Cambridge: Cambridge Universty Press, 2004), p. xx; Anne Orford, "The Past as Law or History? The Relevance of Imperialism for Modern International Law', IILJ Working Paper 2 (2012), 1-17, pp. 11-7; Anne Orford, 'International Law and the Limits of History', in: The Law of International Lawyers: Reading Martti Koskenniemi, ed. by Wouter Werner, Marieke de Hoon, and Alexis Galán (Cambridge: Cambridge University Press, 2017), 297-320, p. 305. 
well as to posit a new canon of international legal history. Juan Pablo Scarfi has placed Scott within the context of the American Institute of International Law and pan-Americanism, and Ignacio Rasilla del Moral has focused on recapturing Scott's institution-building activities. ${ }^{12}$

This article recovers a salient and yet neglected aspect of Scott's work: his firm conviction in American exceptionalism, a belief that underlay both his institutional work as well as his understanding of the origins and trajectory of international law. In the first section, we will discuss Scott's interpretation of Hugo Grotius as part of his broader tactic to make US foreign affairs policies and perspectives more compelling by presenting them as universal. In the second section, we argue that Scott's writings on the Spanish origins of international law were in fact a guise to protect Anglo-American hegemony and US influence in the Americas in the face of rapidly changing geopolitical pressures. And in the last section we suggest that Scott's US exceptionalism is reflected in his use of the United States Constitution and Supreme Court as a model for future international organizations, themselves conceived as tools for projecting American influence globally, and derived from a pervasive assumption of the superiority of American domestic institutions. This section shows that despite ostensible shifts, including his 'Salamancan turn', Scott's US exceptionalism remained unchanged throughout his career. We conclude that through current scholarship, as well as through the institutions of international law he helped to create, Scott's US exceptionalism remains influential partly because he successfully instrumentalized the Salamanca School to mask it. Within his Salamancan turn, Scott reframed Vitoria not to redress American bias but to enshrine it.

Was Grotius the father of modern international law? 'Fathers', like 'moments', have limited analytical use. Equally, however, it is inevitable and at times useful to choose symbols and figures through which to consider a discipline and

12 See Scarfi, The Hidden History of International Law; Paolo Amorosa, 'James Brown Scott's International Adjudication between Tradition and Progress in the United States', Journal of the History of International Law 17 (2015), 15-46; Paolo Amorosa, Rewriting the History of the Law of Nations: How James Brown Scott Made Francisco de Vitoria the Founder of International Law (Oxford: Oxford University Press, 2019), pp. 3, 9-10, 245-312; Paolo Amorosa, The American Project and the Politics of History:James Brown Scott and the Origins of International Law (PhD Dissertation of the University of Helsinki, 2018), p. 3; Ignacio de la Rasilla del Moral, In the Shadow of Vitoria: A History of International Law in Spain, 17701953 (Leiden: Brill, 2017), pp. 139-53. 
its self-representation. Explicit claims of paternity are also significant. Machiavelli, Grotius, Hobbes, Descartes and Locke all claimed to have invented something new. Paternity therefore can be questioned in several ways, by starting from the thinkers' self-assessment or from others' view of their role. James Brown Scott pursued both paths. When he proposed the highly influential series, Classics of International Law, to the Carnegie Endowment for International Peace in 1906, he framed the project as a corrective to the maxim that Grotius is 'the founder of international law'. What Rossi consequently describes as Scott's 'open animosity toward Grotius' is discernible throughout his works. ${ }^{13}$ While still praising the Dutchman for his excellence as a lawyer, statesman and theologian', and describing the enduring significance of his De iure belli ac pacis as derived from 'his eminence in each of these walks of life', Scott characterized Grotius as merely the first 'expounder' and systematizer rather than the founder or father of international law, and cited Thomas Erskine Holland approvingly that the first step in modernizing international law was taken by Gentili..14

To counter the standard narrative of the Grotian foundations of international law, Scott proposed his own stadial theory: Grotius's predecessors in the first stage, Grotius himself in the second, and his successors in the third stage. Grotius is unique not because he invented anything new, Scott explained, but because he systematized and popularized existing arguments, and because he represented an inflection point in international law. ${ }^{15}$ War was assumed to be the default condition of humankind before Grotius; after him, it was peace. ${ }^{16}$ Writing to commemorate the three hundredth anniversary of De iure belli ac pacis, Scott notes,

13 Rossi, Broken Chain of Being, p. ix. On the origins of the Classics series, see Amorosa, Rewriting the History of the Law of Nations, pp. 128-9.

14 James Brown Scott, 'Grotius' De Jure Belli ac Pacis Libri Tres: The Work of a Lawyer, a Statesman and Theologian', The American Journal of International Law 19 (1925), 461-8, p. 466.

15 This is particularly important because, as Amorosa points out, Scott strategically invoked past thinkers as visionaries in order to show that his own views are inevitable. The reader or listener is not asked to trust Scott, but to accept a pious genealogy instead. See Amorosa, The American Project, pp. 35-36. See as well Eric Voegelin's review, in which he accuses Scott of 'judicious omission' to construct a favorable narrative of the development of international law. Eric Voegelin, 'Right and Might', The Review of Politics 3 (1941), 122-3, p. 123 .

16 Scott's view of Grotius curiously echoes the words of M. Auguste Beernaert, President of the First Commission of the Second Hague Conference, who described the Conference in the same terms. Proceedings of the Hague Peace Conference (New York: Oxford University Press, 1920), pp. 272-3, cited in Finch, Adventures in Internationalism, pp. 30-1. 
Perhaps the best comment upon [Grotius's] life and influence is that, although he gave war first place in the rights and duties of nations, any man writing today would give peace that predominance; in other words, the whole standard of thought has been changed, peace being in conception, and bound to be in fact, the normal state of things in any system of law; whereas war is at best an abnormal condition and as such opposed to a settlement of disputes according to any system of law which is itself derived from justice. ${ }^{17}$

While this was certainly to Grotius's credit, the Carnegie Classics of International Law series nevertheless strove to make his predecessors once again widely available by publishing them in English with introductions by leading international lawyers. A competing claim to paternity first had to be uncovered and popularized before Grotius could be dethroned. At the same time, however, Scott wanted to move away from the received historiography by publishing Grotius's works 'cut loose from the mass of editorial note and comment which encumber the text'.18 What Scott meant was a Grotius freed from previous interpretations, as he had originally planned to publish his own 'exhaustive running exposition' of De iure praedae and in fact did include introductions to both Mare liberum and De iure belli ac pacis in the Carnegie editions. ${ }^{19}$ As editions and commentaries on De iure belli ac pacis comprise a substantial proportion of the totality of seventeenth- to nineteenth-century international law texts, Scott's proposal amounted not to recontextualizing Grotius in his own time, but rather to downsizing his importance by removing the layers that attest to and detail his actual influence. In the last stage, the successors of Grotius were to 'be edited and brought within the reach of the American people'. Taken together, Scott proposed that the series be called Corpus Juris Gentium, modeled on Roman and canon law, and he volunteered to be its editor-in-chief. ${ }^{20}$

Scott's work to construct an alternate history of international law manifested itself in his international collaborations, as well. To celebrate the four hundredth anniversary of Francisco de Vitoria's De Indis recenter inventis and De jure belli, Scott began an international project to reclaim these foundations, with four monographs planned: on Augustine by Jan Kosters, Aquinas by Louis

17 Scott, 'Grotius' De Jure Belli ac Pacis', p. 468.

18 Quoted in George Finch, 'Preface' in Hugo Grotius, De iure praedae commentarius (Oxford: Clarendon Press, 1950), p. x.

19 George Finch, 'Preface' in Grotius, De iure praedae, p. xii; James Brown Scott, 'Introduction', in Hugo Grotius, De jure belli ac pacis libri tres (Oxford: Clarendon Press, 1925), pp. ix-xlvi.

Scott to Woodward, 2 Nov. 1906, reprinted as appendix C to Grotius, De iure praedae. 
Le Fur, Vitoria by Scott himself, and Suárez by Alfred Verdross. The aim of this project was to rebuild the 'Temple of international justice' from its foundations to its completion - without a single work spared for Grotius. ${ }^{21}$ According to Scott, the Dutchman's systematization of the law of nations contributed to its popularity, but the underlying principles were to be found in the Spanish Scholastics.

The Carnegie Classics project took off, eventually publishing twenty-two items between 1911 and $195^{\circ}$ (divided into thirty-eight volumes), and bringing in a range of renowned international lawyers to offer introductions to the texts. As Scott himself described it, the aim of this project was nothing less than to 'enable specialists as well as general readers to trace International Law from its faint and unconscious beginnings to its present ample proportions', so that lawyers could 'forecast with some degree of certainty its future development into that law which Mirabeau tells us will one day rule the world'22 This objective also informs the function of Scott's Law, the State, and International Community, the second volume of which brought together quotations from over two millennia of political and legal thought to create a 'codification of the fundamentals of political science and jurisprudence, both national and international'. ${ }^{23}$ Such a project rested on two interrelated propositions: first, in a direct echo of the natural law tradition, that 'justice is universal' and timeless, meaning that the principles established by the Spanish Scholastics were equally valid in Scott's own context; and second, that there is a gradual progression of law 'as the result of centuries and centuries of experience' tending towards its perfection. ${ }^{24}$ This work, taken together with the broader Carnegie Classics produced under his editorship, represent then a highly manicured attempt to recreate the canon of international law so that the desired principles of a future international organization would flow naturally from their alleged origins in Salamanca.

21 James Brown Scott, 'The Two Institutes of International Law', The American Journal of International Law 26 (1932), 87-102, p. 97.

22 James Brown Scott, 'Preface' in Francisco Suárez, Selections from Three Works (Oxford: Clarendon University Press, 1944), p. vii.

23 Scott, Law, the State, and the International Community Vol. I, p. vii.

24 Scott, Law, the State, and the International Community Vol. I, p. 35; James Brown Scott, The Spanish Origins of International Law: Francisco de Vitoria and the Law of Nations (Oxford: Clarendon Press, 1934), pp. 11a-12a. See also Hans Morgenthau, 'Review of Law, the State, and the International Community', Political Science Quarterly 55 (1940), 261-2. 
As Scott and his allies became increasingly concerned about anti-Yankeeism in Latin America in the 1920s, Scott's historiography of international law and his assessment of Grotius also began to change. Scott still referred to the relationship between Salamanca and Grotius as one of innovation and mere exposition, respectively, but he expanded considerably on the idea that the School of Salamanca invented modern international law in response to the discovery of America, which exposed the unsustainability of Eurocentric global law. According to Scott, modern international law as Vitoria invented it proved successful, and continued to grow, because of the dialectic of the Old and New Worlds, which led naturally to the United States as the authoritative model for all international legal bodies, from the International Court of Justice to the League of Nations. As Scott would characterize the Scholastic, 'Victoria was a man of the present, with his eyes turned towards the future. That future was America. The question in his hands was not merely as large as America - large as it is - but as large as our world'. 25

The shift in Scott's work is notable, but it represents an extension rather than a turn. Scarfi has interpreted this shift as Scott moving from a preference for Anglo-American, civilized international law toward pan-American exceptionalism, ${ }^{26}$ while Amorosa has interpreted it as the result of Scott's loss of influence in the scholarly legal discussions' after World War I. ${ }^{27}$ However, these interpretations take Scott at his (published) word and overlook the underlying function of this shift: Scott developed pan-Americanism to conceal and preserve the Anglo-American standard of civilization of international law by rendering it palatable to Latin America, and thereby exert hegemony through emergent international institutions. Scott's first casebook of international law, which offered US and British decisions as authoritative guides, is more openly but not more substantively biased toward Anglo-American international law than his work after the 1920 .

Scott's correspondence from the period highlights the extent to which he was determined to export Anglo-American ideals across the Western Hemisphere. In a letter to Nicholas Butler, Elihu Root's successor as President of the Carnegie Endowment, Scott proposed the translation of a collection of case

\footnotetext{
25 Scott, The Spanish Origins, pp. 4, 62, 80, 96-8. Emphasis added.

26 Scarfi, Hidden History, p. 88.

27 Amorosa, The American Project and the Politics of History, p. 20; Amorosa, Rewriting the History of the Law of Nations, pp. 15, 151-160.
} 
studies on international law into French, to be used at The Hague Academy and by the Commission, since 'the Anglo-American conception is, I believe, theoretically as well as practically, more reasonable and more in accordance with the needs of international intercourse than Continental conceptions, too often based upon mere theory'. According to Butler, Scott's casebooks 'dominated the teaching of international law in the United States for nearly four decades'. ${ }^{28}$ However, Scott's problem with relying on Anglo-American case studies for the purposes of international law was that 'they [Latin Americans] fear us, and they fear our language, and if this collection of cases were in English, they would not consult them, believing that we had some ulterior purpose in having them collected'. Scott therefore proposed a translation of the work, as 'if the Anglo-American cases are put into French, our good friends of the Continent will not balk at the language, but through French, which does not excite their susceptibilities, they will imbibe Anglo-American doctrines'. ${ }^{29}$ For similar reasons, the American Journal of International Law had to be translated as Revista americana de derecho internacional - financed by Carnegie, edited by Scott and published in Washington from 1912, and replaced by Revista de derecho internacional in 1922.

Ingeniously combining pan-Americanism with US exceptionalism from the mid-1920s onwards, Scott identified the real start of international law as the Salamancan response to Columbus's (i.e. Spanish, according to Scott) discovery of America. ${ }^{30}$ In a 1926 series of lectures at the School of Foreign Service at Georgetown, Scott addressed the birth of international legal history. Grotius, he explained, had exaggerated his own importance, given his extensive reliance on Vitoria, Ayala, Vazquez and Covarruvias. The author of De iure belli ac pacis was widely regarded as the father of modern international law, and yet English scholars still claimed that Gentili preceded him, leading Scott to wonder, 'Why stop here? Why stop the pushing process with Gentilis?' Indeed, Vitoria, Ayala, and Suárez had done it all before Grotius, according to Scott. Recalling an anecdote about discussing this very topic at a diplomatic conference with Roscoe Pound, Dean of Harvard Law School, Scott notes that he was

28 William Butler, 'Biographical Materials on James Brown Scott', in ed. Butler, Finch, Adventures in Internationalism, pp. xiii-xxv, xiv.

29 Scott to Butler, 14 April 1924, CEIPR, SO, JBS, B.6o. Emphasis added. Scarfi, Hidden History, pp. 107-8. On Scott endorsing Langdell's emphasis on the case method and the clear significance of Scott's Anglo-American bias in the international law case book, see Amorosa, The American Project, pp. 74, 109-10. Also see Scott, Cases on International Law, Principally Selected from Decisions of English and American Courts (St. Paul: West Publishing, 1922 [1906]).

30 Scott, "The discovery of America and its influence on international law: address of James Brown Scott delivered at the Catholic University of America, February 25, 1929'. Scarfi, Hidden History, p. 172. 
breaics the peace. And indeed, at the opening session of the Institute of International Law held at The Hague last sumer in comemoration of the 300th anniversary of the appearance of Grotius' work, Dr. Loder, President of the Institute, and until recently president - first President, I should say - of the Pernenent Court of International Justice, was bold enowgin to attribute to Grotius the suthorship of the Protocol of Geneva sn honor which sone people think he would reject, Just as he would the questionable honor of having been the father of international law. If we do not lice the expression that he founded international lew", perhaps we may epmloy the phrese of the lecrned Kostors, who, In the course of the year that is past, published en extraordinsry homage to the memory of (?) Grotius in the volune entitled The Jouncations of Internstional Law,

1. J. Zosters, Les Fonderuents du Droit des Gens (1925)

Deginning with the predecessors of Grotius, he analyzes the views of that distinguished author at great length, and then gives a conspectus of the development which has taken place in the last three centuries frou the eppearance of the book. He prefers the expreasion which rather looks to the Iree of Knowledge, seying that the fruit had become ripe, and it only needed a hand to pluck it- and of course, in his thind, that hand was the one of his countrymen.

Grotius has bonef1ted by the great intolerance rizfich has marked the last few centuries of this Christion world of ours. He happened to be a Protestent by birth, and. for that reason the Protestants have looiced upon hin as the great figure, as the founder or the father of International law, to the neglect of his predecessors of the older Faith, or the older form of fath, perhaps it would be better to say. On the other hand, sustrus there Is a reaction against this tiew, because it has been discovered by Ingland the Bnglish (who have a keen eye for the glory of the Island exmire) that one Gentilis, an Italian by birth, whose father had becone a Protestant, and who, sojournine with his father in foreign lands, ultimately reached Ingland, where he became Professor of Civil Law at the University of Oxford, was renlly the foundor of international law. He lald domn in clear and literary language these principles in his three books of the Law of Rar published in 1587, 1588 and 1589. If internationel lam nust have a founder, the partisens

FIGURE 11926 Grotius lectures (unpublished), Georgetown, box 64 folder 6 . Courtesy of The Booth Family Center for Special Collections at Georgetown University Library. 


\section{5}

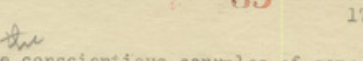

of the present brief had not been to overcome conscientious scruples of some of the shareholders in the captor' 3 company ageinat the cepture and the distribution of its carge as prize to the nembers. Like counsel who rotained in a case make a spocial study of the facts and the law involvod, Grotius had anassed a fund of knowlodge of which he was not unviling to make a display. He himself says "beceuse it is of special importance that this part of the arguent be understood" - the validity of prize was the whole of his case snd substance of hia argumont - "and because othors who have discussed the question of war have not reelly covered thia mattor, it seems best here to recapitulate even the same points which we cleared up the former question" (wer).

It is permisaible to say that writers arenot as a rule over-generous to thoir predecessors. Grotius was not fair, much loss genoroug to his predecessors in the scanty $1 i$ st of names which he onumerated in the Prolegomene to his treatise and in the eoment on Gentilis and Ayala. In the vory first paragraph of the work he more than intimates that no one before him had properly treated the law of nations, although the truth seems to be that the system which he was expourding at length had already been founded and, wers on oxiating body of principles and rules listiver

before he took up his pen, and would have controlled the conduct of nations if the had-mot rribten his treatise on the lav of war and peace or, if written, it had remained unpubliched for gencrations, as was the case with the comaentary on the lav of prize. In any event, Grotius was unfair to his precedessors in the law of prize. They had noth had occasion to propare a monograph on the subject, as-ijeGrotius. Their accounts wore short, to the point, and accurate. The astter would however be a nero trifle if the troatment of prize was not the only clein, according to Pruin, which Grotius makes to originality. An examination of Vitoria, Ayala and Covarruvias anong the Spaniabis, and the De jure belli of Gentilis shows upon what a slender basis the clain rests.

some writers were of the opinion that property in prizo was the occupation of what is knom-in lew as ros nullisus, thet 18 ovnerless property, but the property had an ownex before titio-wes loat by inim and kcquircu by gnother. It was therefore ceg oltepiug and bhor o to bherefore a divesting and an ac quasition or ownor ship. How-isturs cond:

Grotius appesls to laws of the first order set forth in the Prolegomena to the comaentary which "allow us to do everything necessary to the preservation of our lives and our property, without question," he adds, "they ellow the instruents, by which they are harmed, to be destroyed." This is as usual the premise of which

FIGURE 21926 Grotius lectures (unpublished), Georgetown, box 64 folder 2. Courtesy of The Booth Family Center for Special Collections at Georgetown University Library. 
myst take precedence which is the meaning of the universally accepted tradition that one State becoraes the subject of another because of 1 ts orn tranggression." Again why, and again the traditional and universal answer: "Thoever wages a just war becomes to that extent the judge of his adversary, and, In such a case one necessarily has recourse to the law of nature under which everyone was peralt ted to act as a judge in his om case." of a truth, the young Protestant speaks as a learaed Catholle theologian.

It may, however, happen that laws applicable are in conflict. Hence the 13th and last law: There they can be observed at the same time let them be observed: but when that is impossible, then let that 1 aw orevail which is the more worthy. Where we have a hierarchy of laws, one's own good is to be preferred. the greater good to the lesser, the removal of a major evil to the maintenance of a lesser good, Let us talce Grotius' interesting example. He transports you to a desert, puts you in peril of your life, and sets you the trying task of extricating yourself as best you can. What are you to do? You cannot go to the Judge, because there is none at hand. You are relegated to a state of nature, where conventional rights and conventional remedies are non-existent. "Under such circuastances," It is Grotius tho is speaking, "you will be Justified in defending yourself personally without regard to the ninth law in trials. Nay even the third which forbids you to injure another will not be able to stand in your way. since in no other way would you be able to agsert your otrn right in accordance with the first law which entrusts your life to you. Likerise if anyone has property of mine and does not pay me for 1t, but is preparing to flee, so that I have no hope of recalling him for trial ... one must have recourse to the $s 1 x t h$ law which sets forth that the doers of good are to be done well by, and the loss made good by money payment; nor will the fourth law, which forbids one to seize goods of another bar me from recoverjng just so much as itself contributes to existence in accordance with the second law; for no one ought to be compelled to scatter his substance. How long to be judge and executioner in your own behalf? Unt11 "the Imrediate danger of death and loss is past", when the lans again resume their sway.

This is indeed an ingenious way of showing the progress which mankind had made from a lawless to a law preserved world, and shows to perfection Grotius' happy faculty of stating the comonplaces of his subject in such a way as to Eive it the appearance of originality.

A further word and we are through for the present with Grotius' masterly

FIGURE 31926 Grotius lectures (unpublished), Georgetown, box 64 folder 2. Courtesy of The Booth Family Center for Special Collections at Georgetown University Library. 
about to say that Suárez was first, but Pound interrupted to say the very same thing. For Scott, this points to a general understanding 'that if the sun rose in Holland in 1625 , it had been rising previously' in Spanish legal thought. The Dutchman fit into this lineage due to his strong Christianity, which according to Scott verged on Catholicism; however, Grotius's influence on international law, Scott adds, was secondary to the impact of the discovery of America.

Thus, contrary to the dominant historiography of international law, 1625 was merely the third significant date and not its beginning. ${ }^{31}$ Speaking at a banquet held in 1929 to 'celebrate the anniversary of the discovery of the Americas by Christopher Columbus', Scott began his presentation by claiming that 1492,1532 , and 1625 are 'the three dates which form the point of departure of international law' ${ }^{32}$ It was the discovery of America in 1492 that started the process that would lead to modern international law by inspiring Vitoria in 1532 to consider the position of 'the savages of the new world, commonly called Indians, who fell under Spanish domination over forty years ago' and thereby transform Salamanca into 'the cradle of international law'. ${ }^{33}$ This initial development of international law was then systematized by Grotius in 1625. There is thus a direct chain of events beginning with the discovery of the Americas and leading to the creation of modern international law: 'because of the discovery of America, we have Vitoria; because of Vitoria, we have modern international law, to which Suarez provided the necessary philosophy so that it could exist, at the same time, as a branch of philosophy and law; and because of the Spanish School, we have Hugo Grotius and his classic exposition of the principles of international law' ${ }^{34}$ More than merely a historiographical squabble, dethroning Grotius as the founder of international law allowed Scott to relocate the birthplace of international law from the Old World to the New. Even if Salamanca was its 'cradle', it was the discovery of the Americas that acted as the catalyst leading to the creation of international law.

Scott further elaborated these themes in a 1934 Georgetown lecture series, which he turned into a Latin American lecture tour in 1937-8. The Carnegie Endowment published the first iteration of these lectures in 1934 as The Spanish Conception of International Law and of Sanctions. The same year, Clarendon at Oxford published Scott's The Spanish Origins of International Law: Francisco de Vitoria and his Law of Nations, and Georgetown University Press published his Catholic Conception of International Law. Sections of the Spanish

31 For a recent repetition of this historiography, which omits Scott entirely from the interwar peace movement, see Oona Hathaway and Scott Shapiro, The Internationalists and Their Plan to Outlaw War (New York: Simon and Schuster, 2017).

32 Scott, El descubrimiento de América, p. 7.

33 Scott, El descubrimiento de América, pp. 12, 15.

34 Scott, El descubrimiento de América, p. 38. 
Conception and the Spanish Origin appear in the Catholic Conception, with more material added and interleaved on both Salamanca writers, but also adding new sections on Mariana, Thomas Aquinas, the Vindiciae, Buchanan, Bellarmine and James, as a sort of broader context to Vitoria and Suárez, who return at the end of The Catholic Conception in a detailed genealogy of international law. According to Scott, this is the exact international law tradition that America adopted with the 1933 Pan-American Conference in Montevideo. ${ }^{35}$ To understand these $1934-38$ works, the political context is everything: though in the final, 1937 iteration of his casebook on international law Scott claimed to have moved away from deriving the principles and right practice of international law from common law decisions, in these lectures and books his instrumentalization of Salamanca as a vehicle of American exceptionalism reveals a change of tactics, not of objective. ${ }^{36}$

In the Spanish Conception, Scott repeats his claim that Salamanca invented international law in response to Columbus's discovery of the Americas. However, he now adds that in a victory for Christianity 'broken by the Reformation', Salamanca created the international community invoked by the twentieth century. Vitoria turned international law into a science, Suárez supplied its philosophy, and Grotius gave it its 'literary form'. To this day, modern international law is 'Spanish in origin, lay in form, but Catholic in fact'. ${ }^{37}$ Much of what Suárez left to the court of conscience could now be brought to the Permanent Court of International Justice. ${ }^{38}$ Yet the best advances in international law came from common law jurisdictions, according to Scott, perhaps because common law is law without command, and thus analogous to customary international law. ${ }^{39}$

It was Suárez, however, who formulated the enduring principle of humanitarian intervention, which is essentially an act of Christian charity. ${ }^{40}$ In his Law, the State, and the International Community, Scott drew on Suárez more than on any other writer in the history of international law and noted that his work 'summed up and blended into a philosophic whole the best of our legal and our heritage from the ancient and the medieval worlds.'41 International

Scott himself could not attend the conference, but still corresponded with delegates. See 'The Ambassador in Argentina (Weddell) to the Secretary of State' 710.G/307: Telegram, in Foreign Relations of the United States Diplomatic Papers, 1933, The American Republics, Volume IV. Available online at https://history.state.gov/historicaldocuments/frus1933vo4/d41.

36 Scott and Jaeger, Cases on International Law (St. Paul: West Publishing Co., 1937), pp. v-vi.

37 Scott, Spanish Conception, pp. 1-2.

38 Scott, Spanish Conception, p. 12.

39 Scott, Spanish Conception, pp. 19, 92-95. Although Suárez described this well, according to Scott, Spanish Conception, pp. 112-3.

40 Scott, Spanish Conception, p. 54.

41 Scott, Law, The State, and The International Community Vol. I, p. xi. 
law is natural, ergo it is divine law and unchanging sub specie aeternitatis, even though to humans it seems to change because circumstances change, and we discover and rediscover natural laws through time. ${ }^{42} \mathrm{~A}$ cardinal natural and international law is individual liberty, also best stated by Suárez - and in the Declaration of Independence. ${ }^{43}$ Changing circumstances mean that specific formulations of international law vary, even if at their best they correspond to natural law. European international law was the first specific system, and now 'an American international law' was coming into its own. ${ }^{44}$ For Scott, this was a form of regionalism and a secondary ius gentium, which sat easily with new global institutions because they added to, and did not derogate from, either natural law or already existing international law. ${ }^{45}$ Secondary ius gentium, Scott argued, can drive primary ius gentium toward harmony with natural law. At some point the whole world accepted slavery - but Christian states abolished it, and their customary international law first restricted, then changed international law for the better. ${ }^{46}$ According to Scott, that was how Suárez, and the Permanent Court of International Justice, could assess whether state practice constitutes custom. ${ }^{47}$ Similarly, Suárez' advocacy for women's rights was just, but ahead of its time, and it was later validated as correct custom by the US Supreme Court. ${ }^{48}$ On the simplest level, Scott's foregrounding of the Spanish tradition helped him to allay anti-Yankee sentiment by claiming to find the origins of American principles in Spanish authors. Tellingly, this attempt quickly failed. When Alejandro Álvarez, a famous Chilean international lawyer, advocated for the identification of 'American international law' in 1911, Scott publicly criticized the notion - only to propose it later in his own, USderived form. ${ }^{49}$ At the establishment of the American Institute of International Law, Scott proposed the US legal tradition as the foundation, source and authority for 'American international law. 50 Both Secretary of State Charles Evans Hughes and Nicholas Murray Butler, President of Columbia University and later of the Carnegie Endowment, described the Habana Declaration that

42 Scott, Spanish Conception, pp. 62-4, 80, passim.

43 Scott, Spanish Conception, p. 67.

44 Scott, Spanish Conception, pp. 81-4.

45 Scott, Spanish Conception, pp. 81-4, 96.

46 Scott, Spanish Conception, p. 116.

47 Scott, Spanish Conception, p. 118.

48 Scott, Spanish Conception, p. 122.

49 Finch, Adventures, pp. 142-5. On Álvarez and American international law, see Christopher Rossi, Whiggish International Law: Elihu Root, The Monroe Doctrine, and International Law in the Americas (Leiden: Brill, 2019), pp. 49, 54, 93. On Álvarez and Scott, see Amorosa, Rewriting the History of the Law of Nations, pp. 50-53. 
Scott drafted as inspired by the US legal tradition and, endorsed and amplified by the pan-American Institute, a template for European and Asian states and federations to follow. ${ }^{51}$

On a deeper level, however, Scott picked up on the similarity between the 'civilizing' interventionist principles of Salamanca in the sixteenth century, and of the US in the early twentieth century. ${ }^{52}$ The guise of Vitoria's and Suárez' tradition of international legal philosophy was useful in justifying the extension of the Platt doctrine that the US could intervene in Cuba for 'humanitarian' reasons any time it wished. ${ }^{53}$ While Scott had long defended the Platt amendment in public and in private, ${ }^{54}$ the Salamanca School had delivered to him a theoretical foundation for his arguments, with Vitoria presented as the first humanitarian, and even as speaking with the 'voice of humanity'. ${ }^{55}$

In this regard, Scott's preparations for the 1927 Rio de Janeiro Commission of Jurists' attempt to codify pan-American international law are revealing. ${ }^{56} \mathrm{Scott}$ was appointed by the then Secretary of State, Frank Kellogg, with the express order that, in so far as the Commission was an attempt at codification, 'the Delegates of the United States ... should not ... participate in the drafting of new international legislation.' Furthermore, Scott was 'instructed to scrutinize all proposals in the light of the existing treaty arrangements and established policies of the United States of America'.57 His participation was thus to represent US interests at the meeting. Scott's co-delegate at the 1927 Rio Commission likewise mobilized the argument of humanitarian intervention with regards to Cuba, a point that Scott supported. At the conference, Dominican, Mexican and Haitian delegates moved motions to limit the ability of other American states to interfere, with the Haitian delegate proposing that 'No State may in the future directly or indirectly, nor by reason of any motive, occupy

$5^{1} \quad$ Finch, Adventures, pp. 159, 167-8.

$5^{2}$ Scarf, Hidden History, p. 102.

53 Scarfi, Hidden History, p. 50. See as well Scott's plan to build a Palace of the American Academy of International Law in Cuba analogous to the Peace Palace described in ibid., pp. 131-6. On the Platt amendment, see Rossi, Whiggish International Law, pp. 104-109, 148, 184; Amorosa, Rewriting the History of the Law of Nations, pp. 38-9, 54ff.

54 See Amorosa, American Project, pp. 48, 86.

55 Scott on Vitoria as the first humanitarian: James Brown Scott, Spanish Conception; James Brown Scott, 'Asociación Francisco de Vitoria', The American Journal of International Law 22 (1928), 136-9, p. 138. See as well Ernest Nys, 'Introduction', in De Indis De Jure Belli (New York: Wiley \& Sons Ltd, 1917), p. 5 .

$5^{6}$ The significance of this trip, and the letter, are overlooked in Amorosa's account. Amorosa, American Project, p. 181.

57 'The Secretary of State to Dr. James Brown Scott, March 15, 1927', Papers Relating to the Foreign Relations of the United States, 1927, Volume 1, 710.C2/211a. Available online at https://history.state.gov/historicaldocuments/frus1927vo1/d283. 
even temporarily any portion of the territory of another State'. The co-delegate from the United States, Mr. Reeves, responded on Scott's behalf, noting that there must be 'two exceptions to the general rule: first, on grounds of humanity, and second, in self-defense'.58 Furthermore, the United States delegation argued that 'no such act arising out of the consent of a State could be considered as an act of intervention properly so called' precisely because 'any such attempt would be an unacceptable limitation of the State's sovereignty'.59

Scott's position on the Platt Amendment can be traced to its origins: Elihu Root, the former Secretary of State and Scott's mentor, had worked on various drafts. ${ }^{60}$ Root himself would defend the Amendment for acting as 'the anchor of Cuban independence and of Cuban credit. No such revolutions ... are possible there, because it is known to all men that an attempt to overturn the foundations of that government will be confronted by the overwhelming power of the United States'.61 Crucially, Scott approvingly cited his former mentor's defense of American colonialism meant to extend 'the principles of American liberty': 'the problem was to apply those principles which are declared in our constitutions, which embodied the formative idea of the Declaration of Independence that all men are endowed with inalienable rights ... to the customs and the laws of peoples which had come down from the Spain of Philip the Second and the Inquisition.62 Indeed, Root would claim that these ideas were so 'alien to their thoughts and conceptions' that 'in the first instance, they had to be applied at the hand of the military officers' ${ }^{63}$

After the 1933 Pan-American Conference in Montevideo, Scott attempted to radically rehabilitate the agenda of his mentor by casting Root as a precursor to the Good Neighbor policy - despite Root's public defense of military intervention in the Western hemisphere and personal involvement with the Platt amendment. Scott argued that Root 'stated in advance - and in classical terms, although without employing specifically the term neighbor - the policy of the

58 'The Delegates of the United States to the International Commission of Jurists (Scott and Reeves) to the Secretary of State, June 10, 1927', in Papers Relating to the Foreign Relations of the United States 1927, Vol. I, 710.C2/240. Available online at https://history.state.gov/ historicaldocuments/frus1927vo1/d288.

59 Ibid.

6o See James Brown Scott, 'Introductory Note' in Elihu Root, Latin America and the United States (London: Oxford University Press, 1917), p. x; Root, The Military and Colonial Policy of the United States (Cambridge: Harvard University Press, 1916), p. 186. On Scott and Root see Amorosa, Rewriting the History of the Law of Nations, pp. 42-46.

61 Root, Military and Colonial Policy, p. 100.

62 Root, Military and Colonial Policy, p. xv

63 Root, Military and Colonial Policy, p. xv. 
good neighbor towards Latin America'64 All of this meant, for Scott, that the Good Neighbor policy was the logical extension of fundamental American values. He noted that ' $[\mathrm{e}]$ quality of treatment is a principle embedded in our very existence: equality of States of the Union; equality of States in the international community'. This principle of equality, he argued, has been present since the founding moments of the United States: 'we may say in passing that in the 1770's the American Commission to Paris was directed to sign no treaty with France if it were not based upon equality' ${ }^{65}$ More than merely a rescue operation for his mentor's legacy in the face of rapidly changing geopolitical circumstances, and despite clothing it in the guise of a Salamancan tradition, Scott was attempting to show that the basic principles of modern international law were in fact American in their origin.

\section{4 \\ The US as a Covert and an Overt Model: Limits of the Spanish Origins}

The previous sections of this article have shown how Scott denied Grotius's paternal status of international law, attributing that status instead jointly to Suárez and Vitoria, and how Scott turned Grotius into a Spaniard not as part of a pan-American international legal history, but subordinate to the 'civilizing mission' of the United States. One clear and striking sign of this is that while the Spanish-American origin of international law features in all his legal history books, Scott's non-historical works, such as those devoted to the Permanent Court of Justice or the codification of American international law, rely only upon cases, authorities and examples which are Anglo-American, despite Scott's ornamental pleas that the Spanish tradition matters. In these books there is no mention of Salamanca, only of the US Constitutional Convention, the Supreme Court, and British decisions.

At the Hague Convention of 1907, Scott's relentless proposals to reform every aspect of the international legal order, including the establishment of an International Court of Justice, along US or at best Anglo-American lines, led other States to object that they had no wish to 'gradually slip into the Utopia of the United States of the World' ${ }^{66}$ In Scott's later proposal to Carnegie and the

64 James Brown Scott, 'The Good Neighbor Policy', The American Journal of International Law 30 (1936), 287-9o, p. 289. See as well James Brown Scott, 'Treaty-Making under the Authority of the United States', Proceedings of the American Society of International Law 28 (1934), 2-34, p. 15 .

65 Scott, 'The Good Neighbor Policy', p. 288.

66 Finch, Adventures, pp. 41-48. 
public, the renamed Permanent Court of International Justice is still patterned explicitly on the US Supreme Court - even though in his legal history books Scott derived them from the School of Salamanca, in which he included Grotius. For example, Scott claimed that with 'the creation of the international tribunal of the Hague ... following Vitoria's doctrine, in the future, legal action between nations should prevail, in the same way that prevails among individuals within the perfect state. 67

Scott's writings at the end of the Great War illustrate his mobilization of Anglo-American institutions as the source of future international organizations. Scott forcefully argued that the process for creating the League of Nations should be modeled on the constitutional conventions that the 13 colonial states went through to set up the United States, especially the Constitutional Convention of $1787 .{ }^{68}$ For Scott, the constitutional convention showed that it was possible for sovereign states to mutually agree to 'renounce in the interest of all' certain sovereign rights in order to 'form a more perfect Union than that of the Society of Nations' ${ }^{69}$ Indeed, Scott held the formation of the Union to be a 'lamp to their feet' of statesmen after 1918: even if the degree of integration achieved through the American Union proved to be unpalatable, the blueprint for a perfect union had already been drawn, particularly in regard to the creation of an international court based on the United States Supreme Court. This meant that a new international court would 'necessarily be a court of limited jurisdiction; but, with the growth of confidence in that tribunal, its jurisdiction will be enlarged in the way pointed out by the Supreme Court itself. ${ }^{70}$ Over time, Scott foresaw the strengthening of international courts, expanding their power through the gradual consent of member states. 'What the thirteen States of the New World have done', he argues, 'the States of the Old World can assuredly do if only they will, for where there is a will there is a way. ${ }^{71}$

The underlying vision in this regard is 'the substitution of law for physical force' so that 'the conduct of nations, like the conduct of States of the American Union, be guided and eventually controlled by the principles of justice.'. ${ }^{2}$ However, the specific content of Scott's 'principles of justice' were themselves already predetermined by American values embodied in the Declaration of

\footnotetext{
67 Scott, El descubrimiento de América, p. 18.

68 Scarfi, Hidden History, p. 51; Scott, The United States of America: A Study in International Organization (Carnegie, 1920).

69 Scott, The United States of America, p. 467.

70 Scott, The United States of America, p. 282.

71 James Brown Scott, Judicial Settlement of Controversies between the States of the American Union (Oxford: Clarendon Press, 1919), p. 542.

72 Scott, The United States of America, p. 282.
} 
Independence and the United States Constitution. This is evidenced in two of Scott's later articles published in 1936 and 1939, titled respectively 'What does International Law Mean to Us?' and 'The American Conception of International Law'. Despite shifting the title from speaking of international law generally to a specific American conception, these two articles use exactly the same source material to advance the exact same argument: that on 'the $4^{\text {th }}$ day of July, 1776', the Declaration of Independence 'laid the foundations of what we believe is - or should be - the modern state', as well as for a new conception of international law. ${ }^{73}$ Scott sees the Declaration as a new foundation precisely because in the phrase, 'under the Laws of Nature and of Nature's God', the authors had recognized 'the existence of the law of nations and acted under what they conceived to be the precepts of the law of nature. ${ }^{74}$ Furthermore, in enumerating specific rights, such as 'Life, Liberty and the pursuit of happiness', the Declaration gave substance to the law of nature. Additionally, the Declaration set out principles of equality that would be realized through successive moves to expand the franchise and widen the definition of 'We, the People.. ${ }^{75}$ These truths held to be self-evident, according to Scott, were in fact only 'selfevident in the New World. ${ }^{76}$ The rest of the world stood in need of benevolent US enlightenment and indirect but all-encompassing leadership.

The prominent place of arbitration in the rising international legal order proved the value of another Anglo-American contribution to international law. Arbitration was established by John Jay, consolidated by Francis Lieber (as a US citizen, despite his German origins), and after relative decline it was revived once more by the United States. The British-American Alabama Claims tribunal of $1871-72$ then showed the rest of the world the merits of arbitration over open war. The best jurists, Scott explains, then found that the US and Great Britain did not innovate in international law, but admirably codified and actualized what was by then the unwritten law of nations which, in turn, became a model to follow for participants of the First Hague Convention. 'The United States may therefore claim not a little proprietary interest in this great

73 James Brown Scott, 'What Does International Law Mean to Us?' Proceedings of the American Society of International Law 30 (1936), 2-14, p. 3. Scott elsewhere refers to 1776 as an 'epoch-making year'. See James Brown Scott, 'The Progress of International Law during the Last Twenty-Five Years', Proceedings of the American Society of International Law 25 (1931), 2-35, p. 3. On the birth of the modern state based on contract as an American idea, see James Brown Scott, 'Government of Laws and Not of Men', Advocate of Peace through Justice 88 (1926), 36o-8, pp. 361-2.

74 Scott, 'What Does International Law Mean to Us?' p. 3.

75 Scott, 'The Progress of International Law', p. 4; see as well Amorosa, American Project, pp. 267-307.

76 Scott, The United States of America, p. 32. 
convention of 1899', Scott concluded. ${ }^{77}$ His proposal for the Court of Arbitration foresaw a future when the new court would have built up a body of precedents, and could expand its scope and authority as any new common law court would. ${ }^{78}$ Elsewhere, Scott noted Connecticut versus Pennsylvania, settled under the Articles of Confederation, as the great American precedent in international arbitration..$^{79}$ The tradition continued in 1785 with Jay's proposal to use a 'mixed commission' to settle border disputes with the United Kingdom and with the subsequent Jay Treaty, which led to arbitration becoming 'a favored method of settling international disputes' ${ }^{80}$ As a result, 'in both of the great branches of peaceful settlement, judicial and arbitral, the government of the United States has been a pioneer, and if for technical reasons it has not adhered to the Permanent Court of International Justice, it made the court'.81

In addition to substituting law for force, and constructing the instruments of arbitration, Scott argues that the creation of an international court of justice is also an American ideal, found in none other than the words of President Ulysses S. Grant: 'I look forward for a day when there will be a Court established, that shall be recognized by all nations' and which will 'take into consideration all questions of difference between nations, and settle by arbitration or decision of such court, those questions' ${ }^{82}$ Drawing on the history of the United States Supreme Court and the case of The State of Rhode Island $v$. the State of Massachusetts (1838), Scott argues that independent, sovereign states can agree to transform political questions into judicial ones merely by submitting it to a court and allowing it to make a binding decision. Thus, the United States shows a successful precedent for depoliticizing issues: 'What thirteen American States could and did establish ... as a means for the final settlement of controversies ... the civilized States of the world could likewise establish and accept' $^{83}$ This is the exact same argument that Scott had made almost two

77 Finch, Adventures, pp. 33-8, 65-6, 110.

78 Finch, Adventures, p. 82.

79 Scott, 'The Movement Towards Arbitration', Annals of the American Academy of Politics and Social Science 138 (1928), 126-9, p. 126.

$80 \quad$ Scott, 'The Movement Towards Arbitration', p. 128.

81 Scott, 'The Movement Towards Arbitration', p. 128.

82 Scott, 'What Does International Law Mean to Us?' p. 7.

83 Scott, 'What Does International Law Mean to Us?' p. 12. Here as well, Scott approvingly cites and echoes the arguments advanced by his mentor, Elihu Root: 'The extraordinary scope of judicial power in this country has accustomed us to see the operations of government and questions arising between sovereign states submitted to judges who apply the test of conformity to established principles and the rules of conduct embodied in our constitutions ... It is easy, therefore, for Americans to grasp the idea that the same method of settlement should be applied to questions growing out of the conduct of nations'. See 
decades prior in 1919, illustrating the extent to which his American exceptionalism remained constant in his writings. His much-discussed Vitorian turn is therefore Salamancan, given the role he accorded Suárez - but it is also merely cosmetic.

Scott saw the American contribution to the development of international law reach its apotheosis in the principle formulated by President Lincoln as 'right makes might' ${ }^{84}$ For it was Lincoln who 'lights the beacon of morality' in his statement, 'Let us have faith that right makes might, and in that faith let us to the end dare to do our duty as we understand it'. ${ }^{85}$ Indeed, Scott is quite clear that the separation of law from morality, the famous moment of silete theologi, was a failure in the development of international law. Candidly he laments, 'personally, I think that no greater calamity could befall us ... than to withdraw law from morality and to refuse to consider morality as a controlling element in its development'. ${ }^{36}$ Thus, there is a gradual progression from 1776 onwards of a 'moral understanding' of international law, synonymous with a distinctly American conception. ${ }^{87}$ Indeed, Scott argues that United States governments must live up to their own moral ideals, as 'how can we hope to convert others if we ourselves are not converted?'88 Elsewhere, Scott asserts that 'the influence of the United States in the world at large is based on these simple conceptions' of law based on morality. ${ }^{89}$ For the future, 'humanity needs and the world must have the moral interpretation of history': precisely the task Scott had set for himself in articulating the moral basis of international law in the words of great American statesmen. ${ }^{90}$ Thus, it was the words and actions of United States Presidents and Statesmen - Washington, Jefferson, Franklin, Lincoln and others - that provided the moral basis of international law.

Elihu Root, Addresses on International Subjects (Cambridge: Harvard University Press, 1916), pp. 151-2, quoted in Scott, The United States of America, p. iv.

84 James Brown Scott, 'The American Conception of International Law', Proceedings of the American Society of International Law 33 (1939), 1-10, p. 6.

85 Scott, 'The American Conception of International Law', p. 6. See also Scott's claim that President Cleveland 'define[d] the law of nations' in James Brown Scott, 'Next Steps in the Peace Movement', World Affairs 97 (1934), 79-81, p. 80.

86 James Brown Scott, 'The Individual, the State, and the International Community', Proceedings of the American Society of International Law 24 (1930), 15-32, p. 26.

87 Scott, 'The American Conception of International Law', p. 9.

88 James Brown Scott, 'A Single Standard of Morality for the Individual and the State', Proceedings of the American Society of International Law 26 (1932), 10-29, p. 22.

89 James Brown Scott, 'America and Peace', Advocate of Peace through Justice 88 (1926), 66776, p. 670 .

9o Scott, 'A Single Standard of Morality', p. 21. 
In an article from 1930, Scott set out a laundry list of the 'principles of justice' applicable to the relations between states. These principles included the idea that, for example, 'the rules of conduct governing individual relations between citizens or subjects of a civilized state are equally applicable between enlightened nations... that international morality forms an integral part of international law and should control international relations ... that there is, fortunately, such a thing as a public opinion of the world to which individuals, nations and the international community respond'. The basis for these principles is to be drawn neither from the Spanish Scholastics, nor from the work of Hugo Grotius. Instead, Scott declares that 'for each of these contentions I shall invoke the authority of the United States. ${ }^{91}$

The conception and origin of international law was the Salamanca School's reaction to the discovery of America. International law's future, according to Scott, was also Anglo-American. Writing on Armistice Day, Scott quipped, 'An American writer will undoubtedly be pardoned if he insist that the fifty odd nations comprising the society of nations can assuredly do what thirteen States of the American Union have done and ... settle their controversies without destroying themselves and disturbing the peace of the world. ${ }^{92} \mathrm{~A}$ decade later Scott still held the same position, arguing that Europe would have to learn from the example of the New World: 'We of the West ... hope that Europe will find it possible in some way to bend to its will the newer traditions of its own newer world, so that the actions of states, as well as of their peoples, shall be of law and justice. ${ }^{93}$ It is clear, then, that while Scott mobilized the language of Pan-Americanism and the Spanish contributions to the development of international law, he simultaneously attempted to realize a uniquely US conception of international law.

Speaking before the American Society of International Law in 1931, James Brown Scott declared that 'we are living in a new world, in a new atmosphere, a world as different from the world of yesterday as the world of a thousand years ago. ${ }^{94}$ Scott's account of the history of international law, which he regarded as a vital part of its progressive reform, sought to underline Grotius's

\footnotetext{
91 Scott, 'The Individual, The State, and the International Community', 15-32, at p. 15 .

92 Scott, Judicial Settlement of Controversies, p. 543.

93 James Brown Scott, 'American Background to Briand's Vision of a Unified Europe', The American Journal of International Law 24 (1930), 738-42, p. 741.

Scott, 'The Progress of International Law', p. 15.
} 
foundational significance, while at the same time reconstruct what he termed the 'Spanish Origin' of international law located in the thought of Vitoria and Suárez. Yet this historiographical shift did not signal a sincere commitment to pan-Americanism and the equality of neighboring states. Instead, it was deeply imbricated in Scott's enduring faith in American exceptionalism, a continuation of his earlier visions of future courts and institutes patterned on the US Constitution and the Supreme Court. Scott's pro-active and institutionalized elevation of Salamanca in a deceptively pan-American historiography of selfjustifying international law was intrinsically linked with his largely successful initiatives to encourage Latin American international law institutions to model themselves on and ally themselves with US institutions. Scott and his allies favored pan-Americanism not only as informal empire in the Americas, but also because it would have bestowed more global power upon the United States via a pan-American voting block in the new international organizations, including the League of Nations and the Permanent Court of International Justice, that Carnegie, Scott and the US administration were proposing and financing. Only this combination of regionalism and internationalism, underpinned by a very specific American international legal history, could guarantee US influence on the American continents, and globally. Indeed, even as late as 1939, Scott could still predict that 'at some future date the "Supreme Court" of the world will doubtless have unquestioned jurisdiction over all international disputes'.95 Thus, in Scott's narrative of the development of international law, Spain discovered the New World and the Spanish had given birth to modern international law; however, it would be the United States that would chart the path forward to a new international law based on thoroughly American constitutional principles. Scott's Spanish tradition is, in this sense, a red herring. To criticize it for contributing to the Eurocentrism of self-serving genealogies of international law, or for its naïve instrumentalization of Vitoria to back-project historical foundations of pacifism, is to miss the importance, coherence and persistance of Scott's US-centrism. ${ }^{96}$

Furthermore, Scott's continued faith in 'the miracle of the new world' challenges recent critical legal approaches to Scott and Ernest Nys, according to which, for instance, Eurocentrism is one of the biases they introduced. ${ }^{97}$ Their

95 Scott, Law, State, and the International Community, p. 38.

96 Martti Koskenniemi, 'Vitoria and Us: Thoughts on Critical Histories of International Law', Zeitschrift des Max-Planck-Instituts für europäische Rechtsgeschichte 22 (2014), 119-38, p. 134 .

97 Martti Koskenniemi, 'Histories of International Law: Dealing with Eurocentrism', Rechtsgeschichte 19 (2011), 152-76; restated i.a. in Arnulf Becker Lorca, 'Eurocentrism in the History of International Law', in: The Oxford Handbook of the History of International 
preference for Suárez over Grotius (rather than seeing Grotius as these Spanish scholars' successor ${ }^{98}$ ), their view of Catholicism, Scott's forceful proposal of the 1787 US constitutional arrangement as the model for the League of Nations, and his instrumentalization of international legal history and the School of Salamanca to render pan-Americanism palatable to Latin American states taken together, these facts about Scott's work overturn recent theses about both Scott and Nys. To understand Scott, we should think instead of how his project was meant to replace the foundational authority of European sources and provide a theory of 'American international law', by which he meant US international law even when he claimed to identify and foster a continental tradition. Taking account of the American exceptionalism at play in Scott's writings is significant as well for explaining the mediated impact of Suárez and Grotius on the development of modern international law in this half-century of two world wars. The importance attributed to the relationship between Salamanca and Grotius, and the way contemporary scholars fall into camps that prioritize certain comparisons over others, is an inheritance of this project, of which the Carnegie Classics and reams of commentary are only the scholarly manifestation. ${ }^{99}$

\section{Acknowledgements}

The authors thank Prof. Joshua Cherniss, and staff at The Booth Family Center for Special Collections at Georgetown University Library, for their help with the Scott manuscripts. Mark Somos thanks the Deutsche Forschungsgemeinschaft for generous support for his work.

Law, ed. by Bardo Fassbender and Anne Peters (Oxford: Oxford University Press, 2012); Amorosa, The American Project, pp. 15-16.

98 On Grotius as their successor, according to Nys and Scott, see Koskenniemi, 'Colonization of the Indies'. On their view of Vitoria and, more importantly, Suárez, as emphatically not the predecessors but alternatives to Grotius, see Kirstin Bunge, 'Francisco de Vitoria: A Redesign of Global Order on the Threshold of the Middle Ages to Modern Times', in: System, Order, and International Law: The Early History of International Legal Thought from Machiavelli to Hegel, ed. by Stefan Kadelbach et al. (Oxford: Oxford University Press, 2017), $38-54$.

99 While Root and Scott's other allies did not reframe Salamanca the same way, other Carnegie-aligned projects had a similar function. Carnegie served on the US delegation to the First Pan-American Conference of 1889-1890 and paid for the Peace Palace. Scott had the Carnegie Endowment for International Peace finance the American Institute of International Law, as well. Scarfi has pointed to a close connection between pan-Americanism and global peace projects by linking the 1906 Rio de Janeiro and 1907 Hague conferences. See Scarfi, Hidden History, pp. 27, 47. 